\title{
A morphological anomaly in Clausocalanus mastigophorus (Claus, 1863) (Copepoda, Calanoida) from St. Peter and St. Paul Archipelago
}

\author{
Melo, PAMC. ${ }^{a *}$, Melo Júnior, M. ${ }^{b}$, Araújo, M. ${ }^{a}$ and Neumann-Leitão, S. ${ }^{a}$ \\ ${ }^{a}$ Departamento de Oceanografia, Universidade Federal de Pernambuco - UFPE, Av. Arquitetura, s/n, \\ Cidade Universitária, CEP 50670-901, Recife, PE, Brazil

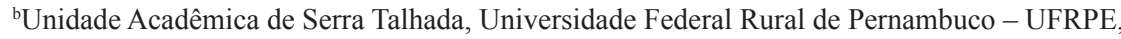 \\ Fazenda Saco, s/n, Zona Rural, CEP 56900-000, Serra Talhada, PE, Brazil \\ *e-mail: pedroamcm@gmail.com
}

Received: November 22, 2012 - Accepted: May 16, 2013 - Distributed: August 31, 2014

(With 1 figure)

Copepods are key species in pelagic marine environments. They act as a link between primary producers and fish and also as predators of other major consumers (Gismervik, 2006). These organisms are the most abundant and diverse constituents of the marine mesozooplankton and the principal secondary producers in marine food webs (Shimode et al., 2006), and they can represent up to $80 \%$ of the biomass of planktonic metazoans in these environments (Kiørboe, 1997). Among Copepoda, Calanoida are noteworthy because they are relatively abundant and diverse under certain conditions (Stephen, 1984). The genus Clausocalanus is one of the most common and abundant genera of calanoids in the oceans, primarily in tropical and subtropical regions (Cornils et al., 2007). In South Atlantic waters, this genus is represented by 12 species (Boltovskoy, 1999). Among these species, Clausocalanus furcatus (Brady, 1883) occupies a dominant position due to its high abundance and frequency. Among the other species of the genus occurring in the South Atlantic is Clausocalanus mastigophorus (Claus, 1863), an epipelagic species that is commonly found in warm shallow waters (Peralba and Mazzocchi, 2004).

Morphological abnormalities are commonly observed in several planktonic crustaceans (Dias, 1999; MartinelliFilho et al., 2009; Sousa et al., 2011). With their great abundance and diversity, copepods are very susceptible to these anomalies (Bayly and Shiel, 2008; Gusmão and McKinnon, 2009). Various causes are associated with these malformations, such as the presence of ecto- and endoparasites, food limitation, UVB radiation and pollution (Lacuna and Uye, 2001; Gusmão and McKinnon, 2009).

An important taxonomic characteristic of Clausocalanus species is the bases of $\mathrm{P} 2$ and $\mathrm{P} 3$, which bear spiniform processes distally (Frost and Fleminger, 1968). Despite minor variations in ornamentation, females of all species of Clausocalanus have only three spines at the base of P3. These spines vary in their relative size, width and distribution in the P3 base.

The present study reports the first observation of a malformation in a female of $C$. mastigophorus. The specimen was collected between depths of 40 and $60 \mathrm{~m}$ near the St. Peter and St. Paul archipelago (SPSPA) (Equatorial Atlantic). This malformation consists of an additional median thorn at the base of the right P3 of the specimen (Figure 1). This anomaly produced an asymmetry in P3 in this individual. The specimen exhibited 3 and 4 spines at the base of the left P3 (normal) and the right P3 (anomalous), respectively.
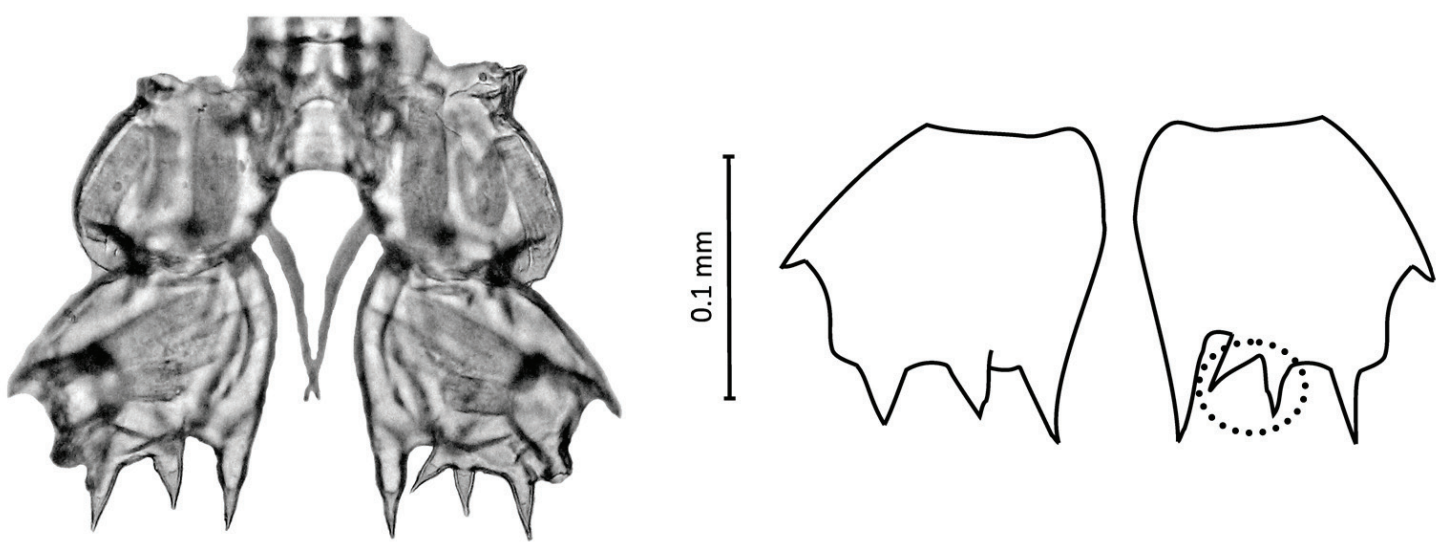

Figure 1. Photo and schema of anomaly observed at the base of $\mathrm{P} 3$ of a female of Clausocalanus mastigophorus in a sample collected at the Archipelago of St. Peter and St. Paul. Note the presence of an additional process in the right P3. 
Cornils et al. (2007), studying the Clausocalanidae of the Red Sea, recorded the development of 1 or 2 additional articules in the fifth pair of legs (P5) on various species of the genus Clausocalanus. The authors suggest that this anomaly can be related to parasitic infestation. However, the results of the current study failed to reveal any sign of infestation, either in the anomalous individual or in any other individual of the same genus in the samples. Moreover, no other species in the samples presented any type of anomaly.

The cause of the malformation observed in the anomalous $C$. mastigophorus is most likely attributed to an error of development or related to random genetic mutations because major anomaly-causing man-made agents have not been observed in the SPSPA, an area uninfluenced by any type of pollution. Studies on the rates of occurrence of this and other types of anomalies should be performed relative to the possible morphologic spectrum that certain species may present or even in terms of the possible ecological impact of anomalous individuals on these populations.

\section{References}

BAYLY, IAE. and SHIEL, RJ., 2008. Intersexuality in Boeckella Triarticulata (Thomson, 1883) (Copepoda, Calanoida): a trap for unwary taxonomists. Crustaceana, vol. 81, no. 3, p. 299-304. http://dx.doi.org/10.1163/156854008783564109.

BOLTOVSKOY, D., 1999. South Atlantic Zooplankton. Leiden: Backhuys. 1706 p.

CORNILS, A., NIEHOFF, B., RICHTER, C., AL-NAJJAR, T. and SCHNACK-SCHIEL, SB., 2007. Seasonal abundance and reproduction of clausocalanid copepods in the northern Gulf of Aqaba (Red Sea). Journal of Plankton Research, vol. 29, no. 1, p. 57-70. http://dx.doi.org/10.1093/plankt/fbl057.

DIAS, CO., 1999. Morphological abnormalities of Acartia lilljeborgi (Copepoda, Crustacea) in the Espírito Santo Bay (E.S. Brazil). Hydrobiologia, vol. 394, p. 249-251. http://dx.doi. org/10.1023/A:1003502624336.

FROST, B. and FLEMINGER, A., 1968. A revision of the genus Clausocalanus (Copepoda: Calanoida) with remarks on distributional patterns in diagnostic characters. Berkeley: University of California Press. 235 p.

GISMERVIK, I., 2006. Top-down impact by copepods on ciliate numbers and persistence depends on copepod and ciliate species composition. Journal of Plankton Research, vol. 28, no. 5, p. 499-507. http://dx.doi.org/10.1093/plankt/fbi135.

GUSMÃO, LFM. and MCKINNON, AD., 2009. Sex ratios, intersexuality and sex change in copepods. Journal of Plankton Research, vol. 31, no. 9, p. 1101-1117. http://dx.doi.org/10.1093/ plankt/fbp059.

KIØRBOE, T., 1997. Population regulation and role of mesozooplâncton in shaping marine pelagic food webs. Hydrobiologia, vol. 363, no. 1-3, p. 13-27. http://dx.doi. org/10.1023/A:1003173721751.

LACUNA, DG. and UYE, S-I., 2001. Influence of mid-ultraviolet (UVB) radiation on the physiology of the marine planktonic copepod Acartia omorii and the potential role of photoreactivation. Journal of Plankton Research, vol. 23, no. 2, p. 143-156. http:// dx.doi.org/10.1093/plankt/23.2.143.

MARTINELLI-FILHO, JE., MELO-JÚNIOR, M., CUNHA, DR. and LOPES, RM., 2009. Rare sexual anomalies in Temora stylifera (Dana, 1849) (Copepoda: Calanoida). Brazilian Journal of Biology, vol. 69, no. 2, p. 455-456. http://dx.doi.org/10.1590/ S1519-69842009000200031.PMid:19675952

PERALBA, À. and MAZZOCCHI, MG., 2004. Vertical and seasonal distribution of eight Clausocalanus species (Copepoda: Calanoida) in oligotrophic waters. ICES Journal of Marine Science: Journal du Conseil, vol. 61, no. 4, p. 645-653. http:// dx.doi.org/10.1016/j.icesjms.2004.03.019.

SHIMODE, S., TODA, T. and KIKUCHI, T., 2006. Spatio-temporal changes in diversity and community structure of planktonic copepods in Sagami Bay, Japan. Marine Biology, vol. 148, no. 3, p. 581-597. http://dx.doi.org/10.1007/s00227-005-0093-3.

SOUSA, FD., ELMOOR-LOUREIRO, LM. and SOUZA, MB., 2011. Occurrence of abnormalities on labral keel of Coronatella monacantha (Cladocera, Anomopoda, Chydoridae) in a population from Ceará, Brazil. Brazilian Journal of Biology, vol. 71, no. 3, p. 797-798. http://dx.doi.org/10.1590/S1519-69842011000400027. PMid:21881806

STEPHEN, R., 1984. Distribution of Calanoid copepods in the Arabian Sea and Bay of Bengal. Mahasagar. Bulletin of the National Institute of Oceanography, vol. 17, no. 3, p. 161-171. 